\title{
Oral and Maxillofacial Complex Lesions in Adolescents: A Retrospective Study of 20 Years
}

\author{
Lesiones Orales y del Complejo Maxilofacial en Adolescentes: \\ Un Estudio Retrospectivo de 20 Años
}

\author{
Josi K. Amadeu*; Juliana L. Schussel*; Cleto M. Piazzetta*; Cassius C. Torres-Pereira* \& José M. Amenábar*
}

AMADEU, J. K.; SCHUSSEL, J. L.; PIAZZETTA, C. M.; TORRES-PEREIRA, C. C. \& AMENÁBAR, J. M. Oral and maxillofacial complex lesions in adolescents: a retrospective study of 20 years. Int. J. Odontostomat., 9(1):113-118, 2015.

ABSTRACT: Studies assessing the prevalence of oral lesions show that $5.2 \%$ to $12.8 \%$ of biopsy specimens are from children and adolescents. In Brazil, there are few studies analyzing the distribution of oral lesions in that population. Therefore, the aim of this study was to evaluate the distribution of oral and maxillomandibular lesions of adolescents, admitted to the Department of Oral Diagnosis of the Federal University of Paraná (UFPR) from 1994 to 2013. A study based on the review of the charts was done and the lesions were classified in 11 categories: salivary glands disease, dental pathology, gingival and periodontal pathology, odontogenic cysts, odontogenic tumors, non odontogenic cysts, bone pathology, mucosal pathology, connective tissue pathology, malignant tumors and other pathology. Variables including age, sex, ethnicity, diagnosis and lesion location were also evaluated. Upon analysis, 376 lesions were identified, most in girls, $51.9 \%$ and 77.1 $\%$ of patients were white. The most frequent site was the lower lip followed by the gingiva. Mucocele was the most common lesion (27.6\%), followed by fibroepithelial hyperplasia $(8.2 \%)$ and pyogenic granuloma (5.3\%). Although there is a wide range of pathologies that can occur in the oral cavity, traumatic injuries are the most common in this age group.

KEY WORDS: adolescent, epidemiology, stomatology, oral pathology, oral medicine, oral mucosa.

\section{INTRODUCTION}

Epidemiological studies are important tools to improve diseases understanding and to establish treatment and prevention protocols. Many studies in the literature on oral and maxillofacial lesions in children and adolescents can generally be found, but they usually focus on histological aspects of biopsied lesions (Jones \& Franklin, 2006). Nonetheless, most lesions diagnosis can be made only by clinical examination (Shulman, 2005).

Some studies report the prevalence of oral and maxillofacial lesions conducting epidemiological surveys about dental and periodontal diseases, malocclusion and dental traumas (Lawoyin, 2000; Wang et al., 2009; Rioboo-Crespo et al., 2005). Others studies only identify and report specific groups of diseases. Therefore, the prevalence of oral lesions in children and adolescents presents considerable variation according to studies in different geographic regions (Lawoyin; Gültelkin et al., 2003; Jones \& Franklin; Lima et al., 2008; Wang et al.).
Studies on the prevalence of oral and maxillofacial lesions are important for characterizing the most frequent lesions in specific population. When it comes to oral lesion studies in adolescents, all the studies include children. As far as we know there are no studies focusing only on adolescents. The aim of this study was to evaluate the distribution of oral and maxillofacial lesions in adolescents between 12 and 18 years old.

\section{MATERIAL AND METHOD}

A retrospective cross-sectional study was designed using clinical charts from the Oral Diagnosis Clinic of the Federal University of Paraná (UFPR), Brazil, from January 1994 to December 2013. Only the charts from patients aged between 12 and 18 years old were included. Data regarding age, sex, race, number of lesions, anatomical site of the lesion and 
clinical and/or histopathological diagnosis were collected. The study was approved by the local Research Ethics Committee (protocol $\mathrm{n}^{\circ}$ 810.145.09.10).

The lesions were separated based on the classification proposed by Jones \& Franklin, but excluding the normal tissue group: 1) salivary glands disease, 2) mucosal pathology, 3) dental pathology, 4) gingival and periodontal pathology, 5) odontogenic cysts, 6) odontogenic tumors, 7) non odontogenic cysts, 8) bone pathology, 9) connective tissue pathology, 10) malignant tumors, and 11) other pathology.

\section{RESULTS}

During the 20-year period, 489 adolescents were attended at the clinic. After chart analysis, 129 cases were excluded due to lack of information. Three hundred and sixty dental records were included with a total of 376 lesions, where 195 (51.90\%) were from females and $181(48.10 \%)$ were from males. Two hundred and ninety $(77.10 \%)$ patients were white, 81 $(21.60 \%)$ were non-white and $5(1.30 \%)$ cases were not specified.

The distribution of lesions shows a decrease of incidence with aging from $18.35 \%$ at 12 and 14 years old to $10.10 \%$ at 18 years old (Fig. 1). Lower lip was the most commonly affected site $(28.45 \%)$, followed by the gingiva region $(15.42 \%)$, and the tongue (11.17\%) (Fig. 2). The most common conditions were mucocele $(27.6 \%)$, followed by fibroepithelial hyperplasia (8.2\%), pyogenic granuloma (5.3\%), ranula and dentigerous cysts (4.5\%). Regarding the diagnosis categories, the largest number of lesions represented the salivary gland diseases, mucosal pathology, and other pathology, in this order (Table I).

In almost $50 \%$ of cases only clinical diagnosis was sufficient to decide treatment and follow-up management. Mucocele had the highest prevalence either for the salivary gland disease category (84.55\%) or for the total cases studied $(27.65 \%)$ (Table I).

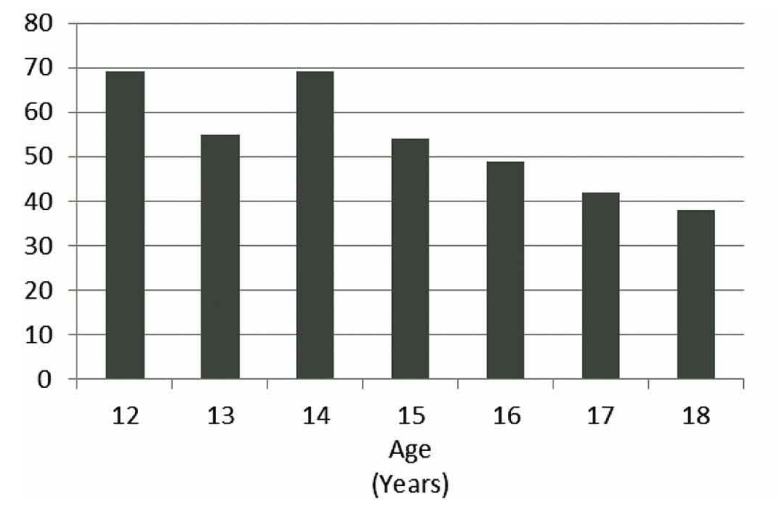

Number of lesions

Fig. 1. Number of lesions distribution according to the age.

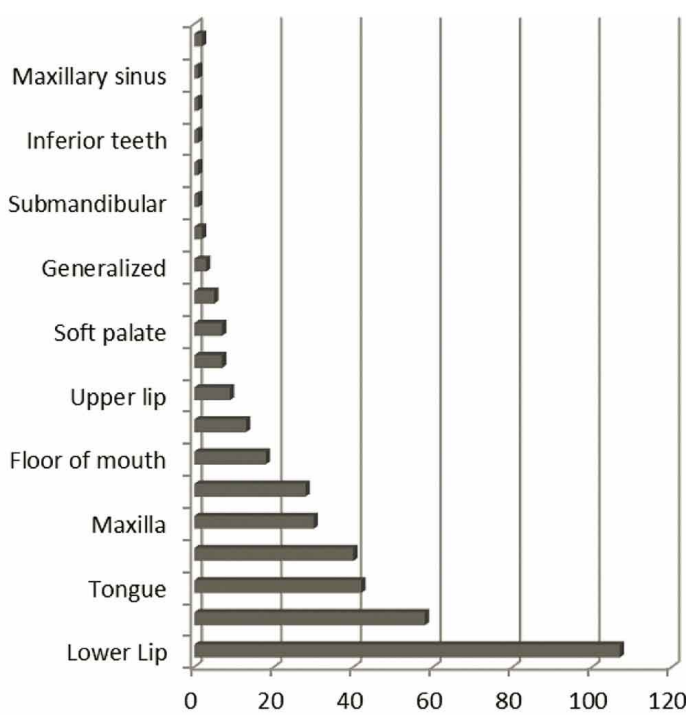

Number of lesions

Fig. 2. Lesion distribution according to location. 
Table I. Distribution of the most common diagnosis in each category.

\begin{tabular}{|c|c|c|c|c|c|}
\hline & & $12-13(n)$ & $14-15(n)$ & $16-17-18(n)$ & Total (n) \\
\hline Salivary Gland & Mucocele & 40 & 31 & 33 & 104 \\
\hline \multirow{3}{*}{ Disease } & Ranula & 6 & 8 & 3 & 17 \\
\hline & Pleomorphic adenoma & --- & 1 & --- & 1 \\
\hline & Chronic sialoadenitis & --- & 1 & --- & 1 \\
\hline \multirow{16}{*}{ Mucosal Pathology } & Fibroepithelial hyperplasia & 6 & 11 & 14 & 31 \\
\hline & Papilloma & 4 & 6 & 4 & 14 \\
\hline & Irritative hyperkeratosis & 4 & 2 & 7 & 13 \\
\hline & Benign migratory glossitis & 1 & 6 & 4 & 11 \\
\hline & Recurrent aphtous ulcerations & 2 & 3 & 1 & 6 \\
\hline & Traumatic ulcer & 3 & 1 & 2 & 6 \\
\hline & Fibroma & 3 & 1 & 2 & 6 \\
\hline & Fibrosis & 2 & --- & 2 & 4 \\
\hline & Actinic cheilitis & --- & 2 & 1 & 3 \\
\hline & Melanin pigmentation & 1 & --- & 2 & 3 \\
\hline & Melanocytic nevus & 1 & 1 & 1 & 3 \\
\hline & Hyperkeratosis and acanthosis & 1 & 1 & 1 & 3 \\
\hline & Verruca vulgaris & 1 & 1 & --- & 2 \\
\hline & Mucositis & 1 & --- & --- & 1 \\
\hline & Amalgam tattoo & --- & --- & 1 & 1 \\
\hline & Lichen planus & --- & --- & 1 & 1 \\
\hline \multirow[t]{4}{*}{ Dental Pathology } & Supernumerary tooth & 5 & 2 & 1 & 8 \\
\hline & Amelogenenis imperfecta & 1 & 4 & 2 & 7 \\
\hline & Hypodontia & 4 & 2 & --- & 6 \\
\hline & Microdontia & 1 & --- & --- & 1 \\
\hline \multirow{5}{*}{$\begin{array}{l}\text { Periodontal and } \\
\text { Gingival Pathology }\end{array}$} & Pyogenic granuloma & 4 & 4 & 12 & 20 \\
\hline & Gingival fibromatosis & 2 & 3 & 2 & 7 \\
\hline & Necrotizing ulcerative gingivitis & 1 & 2 & 3 & 6 \\
\hline & Peripheral ossifying fibroma & 1 & 3 & --- & 4 \\
\hline & Peripheral giant cell granuloma & 2 & 2 & --- & 4 \\
\hline \multirow[t]{4}{*}{ Odontogenic Cysts } & Dentigerous cyst & 6 & 3 & 8 & 17 \\
\hline & Eruption cyst & 1 & 2 & --- & 3 \\
\hline & Odontogenic cyst & --- & 1 & --- & 1 \\
\hline & Paradental cyst & --- & --- & 1 & 1 \\
\hline \multirow{2}{*}{$\begin{array}{l}\text { Odontogenic } \\
\text { Tumor }\end{array}$} & Odontoma & 3 & 2 & 2 & 7 \\
\hline & Keratocyst odontogenic tumor & 4 & --- & --- & 4 \\
\hline \multirow{3}{*}{$\begin{array}{l}\text { Non Odontogenic } \\
\text { Cysts }\end{array}$} & Traumatic cyst & 2 & 3 & 2 & 7 \\
\hline & Epidermoid cyst & --- & 1 & 1 & 2 \\
\hline & Maxillary sinus cyst & --- & --- & 1 & 1 \\
\hline \multirow{5}{*}{ Bone Pathology } & Fibrous dysplasia & 3 & --- & 1 & 4 \\
\hline & Focal sclerosing osteomyelitis & --- & --- & 3 & 3 \\
\hline & Exostosis & 1 & 1 & 1 & 3 \\
\hline & Albright hereditary & --- & --- & 1 & 1 \\
\hline & Central giant cell granuloma & --- & --- & 1 & 1 \\
\hline Connective Tissue & Hemangioma & 1 & 4 & 2 & 7 \\
\hline Pathology & Neurofibroma & 1 & 1 & --- & 2 \\
\hline Malignant Tumors & Ameloblastoma & 1 & --- & 1 & 2 \\
\hline 11. Other & Recurrent herpes labialis & 3 & 2 & 1 & 6 \\
\hline \multirow[t]{5}{*}{ Pathology } & Hypohidrotic ectodermal & 3 & 2 & --- & 5 \\
\hline & Primary herpetic & --- & --- & 2 & 2 \\
\hline & Angular cheilitis & 1 & --- & --- & 1 \\
\hline & Pseudomembranous & --- & --- & 1 & 1 \\
\hline & Candidiasis & & & 1 & 1 \\
\hline Total (n) & 127 & 127 & 120 & 129 & 376 \\
\hline
\end{tabular}




\section{DISCUSSION}

Age is an important parameter when the clinical diagnosis of certain lesions is being considered and most studies from oral lesion prevalence include children and adolescents in the same group. In this study only adolescents were selected and all lesions that occurred were investigated and diagnosed by clinical and/or histopathological examination, whereas $49.46 \%$ of them were exclusively diagnosed by clinical examination. However most studies conclude their diagnosis based on the histopathological analysis (Chen et al., 1998; Sousa et al., 2002; Jones \& Franklin; Dhanuthai et al., 2007; Wang et al.).

Some difficulties such as lack of information on dental records, disparity of age groups, and different lesion classifications reflect on the prevalence of each lesion in different studies, causing errors during results interpretation, making it difficult to compare data found in the literature (Furlanetto et al., 2006). This study is characterized as a specific population study, and the results cannot be generalized. However, it is possible to compare with populations that have similar characteristics.

Oral lesions in adolescents were more frequent in female. In addition, lesions were more prevalent during age-range from 12-14 years, similar to that reported by most authors (Chen et al.; Sousa et al.; Jones \& Franklin; Wang et al.; Vale et al., 2013).

Mucocele was the most common lesion diagnosed, representing $27.65 \%$ of all oral lesions and $84.55 \%$ of the salivary gland disease group. Studies worldwide confirm mucocele as the most common lesion in soft tissues, after histopathological analysis (Skinner et al., 1986; Das \& Das, 1993; Chen et al.; Sousa et al.; Jones \& Franklin; Lima et al.; Wang et al.; Siadati et al., 2013; Vale et al.). Mucocele has uncertain etiology, but can be induced by local trauma (Jaafari Ashkavandi et al., 2013), which is frequent at this age-range. Therefore, the findings are in agreement with lesion's epidemiological characteristics. Although salivary gland tumors are rare in adolescents, special attention should be given to them. In this study, only one case of pleomorphic adenoma was diagnosed, and Vale et al., had the same result.

The mucosal pathology was the second most prevalent group in this study, with $26.6 \%$ of the total. For Jones \& Franklin, this group represented $12 \%$.
Fibroepithelial hyperplasia with $31 \%$ of the category and $8.2 \%$ of total lesions. Similar result was found by Das \& Das with $8.8 \%$ and Maia et al. (2000) with $8.3 \%$. A higher prevalence was found by Skinner et al., with $10 \%$. In the studies of Dhanuthai et al., Lima et al. and Wang et al., the hyperplasia appears with a lower prevalence, with $3.2 \%, 2 \%$ and $2.5 \%$, respectively.

The periodontal and gingival pathology category was the third most frequent, with $11 \%$ of all cases registered, a similar percentage was found by Sousa et al. The pyogenic granuloma was the most frequent of this category with $48.7 \%$ and represented $5.3 \%$ of the total lesions. Other studies found lower results, such as Jones \& Franklin with $3 \%$, Lima et al., with $2.5 \%$ and Wang et al. with $2.8 \%$. In contrast, the study from Avelar et al. (2008), Recife - Brazil had a prevalence of $28.2 \%$.

Fibroepithelial hyperplasia and pyogenic granuloma in adolescents can be caused by parafunctional habits and/or orthodontic devices associated with poor oral hygiene, which can be prevented through orientation and health oral habits (Jafarzadeh et al., 2006).

The dentigerous cyst is the most common cyst on oral and maxillofacial region. It is a developmental odontogenic cyst originated from the reduced enamel epithelium with uncertain etiology. Usually it is diagnosed in routine radiographs due an unerupted tooth but can cause volume increase. It was the most common odontogenic cyst found, $77.2 \%$ and $4.5 \%$ of total lesions studied. This percentage was inferior when compared with other studies. Closer results were found from Das \& Das, with $5.2 \%$, Cavalcante et al. (1999), with 5.6\%, Lawoyin, with $7.5 \%$, and Sousa et al., with $6.5 \%$. The samples from Maia et al. and Wang et al. observed a frequency of $13.1 \%$ and $10.5 \%$, respectively. Superior results values were reported by Dhanuthai et al., in Thailand, with $20.7 \%$, and Shah et al. (2000) in USA, with $24 \%$.

For the bone category, fibrous dysplasia showed a prevalence of $1.06 \%$ for total lesions and $33.3 \%$ in the group. When compared with the data from Keszler et al. (1990), with $10.2 \%$, and Lawoyin, with $5.2 \%$, the results found in the present study and the ones from Jones \& Franklin, Lima et al., and Wang et al., were lower. 
In the connective tissue pathology group, hemangioma was the most common with 7 cases, representing $77.7 \%$ of them. On Jones \& Franklin survey, they identified $34(23.2 \%)$ cases of hemangioma from 146 lesions classified in this group.

Odontoma was the most common odontogenic tumor in previous reports from literature (Sousa et al.; Shah et al., 2009). Odontoma represented $3.76 \%$ of total lesions and $63.6 \%$ of the category, being similar with the findings from Das \& Das and Maia et al. Higher values were found by Dhanuthai et al., Sousa et al., Shah et al. and Wang et al., with 6.1\%, 4.8\%, 6.0\% and $10.8 \%$, respectively.

During a survey realized in the literature, the ameloblastoma presented a low prevalence in European countries (Jones \& Franklin) and America (Shah et al.), it was high in the African and Asiatic continent (Lawoyin, Dhanuthai et al.) and in developing countries (Guerrisi et al., 2007). Dhanuthai et al., justify this higher prevalence with the fact that the patients searched for treatment later. The present study found only 2 ameloblastomas, and both in females. Lima et al., in 625 and Maia et al., in 1.018 biopsies did not find lesions and Das \& Das, analyzed 2.370 samples, found only 5 cases. Lawoyin observed 568 lesions and found $80(14.3 \%)$ ameloblastomas and Dhanuthai et al., in Thailand, observed 1.251 samples and found $106(8.5 \%)$ ameloblastomas.

Recurrent herpes labialis is caused by the Herpes Simplex Virus Type 1 (HSV-1), transmitted through direct contact with infected lesions. The prevalence herpes simplex infection increases progressively from childhood and diagnosis can be made clinically. It represented $1.6 \%$ of total lesions, on this study. Parlak et al. (2006) had in their study a prevalence of $2.9 \%$ for the total oral lesions classified.

Some lesions such as pleomorphic adenoma, chronic sialoadenitis, mucositis, amalgam tattoo, lichen planus, microdontia, paradental cyst, maxillary sinus cyst, central giant cell granuloma, angular cheilitis and candidiasis presented only one case of each inthe study. Jones \& Franklin and Wang et al. commented in their papers that malignant tumors represented about $1 \%$ of all cases, becoming less frequent but possible to occur in adolescents.

Although there is a wide range of pathologies that can occur in the oral cavity, the traumatic injuries, as mucocele, fibroepithelial hyperplasia and pyogenic granuloma, are the most common in this age group. The largest number of cases was recorded in the age group between 12 and 14 years old and the lower lip was the most commonly affected site. The white female patients had the higher number of lesions on the population studied. We diagnosed 52 different types of lesions in adolescents, some common and others uncommon. This shows the variety of injuries that can occur in the oral mucosa and maxillomandibular complex in this age group, alerting professional specialty to enhance the study that field and arouse the interest of the general practitioner and dentist, in diagnosis, treatment and prevention of these injuries.

AMADEU, J. K.; SCHUSSEL, J. L.; PIAZZETTA, C. M.; TORRES-PEREIRA, C. C. \& AMENÁBAR, J. M. Lesiones orales y del complejo maxilofacial en adolescentes: un estudio retrospectivo de 20 años. Int. J. Odontostomat., 9(1):113-118, 2015.

RESUMEN: Los estudios que evalúan la prevalencia de lesiones orales muestran que entre el $5,2 \%$ hasta el $12,8 \%$ de las muestras de biopsia corresponden a niños y adolescentes. En Brasil, hay pocos estudios que hayan analizado la distribución de las lesiones orales enesa población. Por lo tanto, el objetivo de este estudio fue evaluar la distribución de las lesiones orales y maxilofaciales de adolescentes, ingresados en el Servicio de Diagnóstico Oral de la Universidad Federal de Paraná (UFPR) entre 1994 a 2013. Se llevó a cabo la revisión de historias clínicas y las lesiones halladas fueron clasificadas en 11 categorías: enfermedad de glándulas salivales, patología dental, patología gingival y periodontal, quistes odontogénicos, tumores odontogénicos, quistes no odontogénicos, patología ósea, patología de la mucosa, patología del tejido conectivo, tumores malignos y otras patologías. También se evaluaron otras variables como edad, género, etnia, diagnóstico y localización de la lesión. Luego del análisis, se identificaron 376 lesiones, la mayoría en niñas (51,9\%), siendo el $77,1 \%$ de los pacientes de raza blanca. La localización más frecuente fue el labio inferior seguida de la encía. El mucocele fue la lesión más común $(27,6 \%)$, seguido de hiperplasia fibroepitelial $(8,2 \%)$ y granuloma piógeno $(5,3 \%)$. Aunque existe una amplia serie de patologías que pueden ocurrir en la cavidad oral, las lesiones traumáticas son las más comunes en este grupo de edad.

PALABRAS CLAVE: adolescente, epidemiología, estomatología, patología oral, medicina oral, mucosa oral. 


\section{REFERENCES}

Avelar, R. L.; Antunes, A. A.; de Carvalho, R. W. F.; Santos, T. S.; de Oliveira Neto, P. J. \& Andrade, E. S. S. Granuloma piogênico oral: um estudo epidemiológico de 191 casos. $R$. G. O., 56(2):131-5, 2008.

Cavalcante, A. S. R.; Marsilio, A. L.; Kühne, S. S.; \& Carvalho, Y. R. Lesões bucais de tecido mole e osseo em crianças e adolescentes. Pós-Grad. Rev. Fac. Odontol. São José dos Campos, 2(1):67-75, 1999.

Chen, Y. K.; Lin, L. M.; Lin, C. C. \& Yan, Y. H. Palatal pleomorphic adenoma in a child with osteoid formation: report of case. A. S. D. C. J. Dent. Child., 65(3):209-11, 1998.

Das, S. \& Das, A. K. A review of pediatric oral biopsies from a surgical pathology service in a dental school. Pediatr. Dent., 15(3):208-11, 1993.

Dhanuthai, K.; Banrai, M. \& Limpanaputtajak, S. A retrospective study of paediatric oral lesions from Thailand. Int. J. Paediatr. Dent., 17(4):248-53, 2007.

Furlanetto, D. L.; Crighton, A. \& Topping, G. V. Differences in methodologies of measuring the prevalence of oral mucosal lesions in children and adolescents. Int. J. Paediatr. Dent., 16(1):31-9, 2006.

Guerrisi, M.; Piloni, M. J. \& Keszler, A. Odontogenic tumors in children and adolescents. A 15-year retrospective study in Argentina. Med. Oral Patol. Oral Cir. Bucal, 12(3):E180-5, 2007.

Gültelkin, S. E.; Tokman, B.; \& Türkseven, M. R. A review of paediatric oral biopsies in Turkey. Int. Dent. J., 53(1):26-32, 2003.

Jaafari Ashkavandi, Z.; Dehghani Nazhvani, A. \& Hamzavi, M. Mucocele accompanied by a traumatic neuroma: a case report. J. Dent. (Shiraz), 14(1):46-8, 2013.

Jafarzadeh, H.; Sanatkhani, M. \& Mohtasham, N. Oral pyogenic granuloma: a review. J. Oral Sci., 48(4):167-75, 2006.

Jones, A. V. \& Franklin, C. D. An analysis of oral and maxillofacial pathology found in adults over a 30 -year period. J. Oral Pathol. Med., 35(7):392-401, 2006.

Keszler, A.; Guglielmotti, M. B. \& Dominguez, F. V. Oral pathology in children. Frequency, distribution and clinical significance. Acta Odontol. Latinoam., 5(1):39-48, 1990.

Lawoyin, J. O. Paediatric oral surgical pathology service in an African population group: a 10 year review. Odontostomatol. Trop., 23(89):27-30, 2000.

Lima, G. S.; Fontes, S. T.; de Araújo, L. M.; Etges, A.; Tarquinio, S. B. \& Gomes, A. P. A survey of oral and maxillofacial biopsies in children: a single-center retrospective study of
20 years in Pelotas-Brazil. J. Appl. Oral Sci., 16(6):397-402, 2008.

Maia, D. M.; Merly, F.; Castro, W. H. \& Gomez, R. S. A survey of oral biopsies in Brazilian pediatric patients. A. S. D. C. J. Dent. Child., 67(2):128-31, 83, 2000.

Parlak, A. H.; Koybasi, S.; Yavuz, T.; Yesildal, N.; Anul, H.; Aydogan, I.; Cetinkaya, R. \& Kavak, A. Prevalence of oral lesions in 13- to 16-year-old students in Duzce, Turkey. Oral Dis., 12(6):553-8, 2006.

Rioboo-Crespo, M. R.; Planells-del Pozo, P. \& Rioboo-García, $R$. Epidemiology of the most common oral mucosal diseases in children. Med. Oral Patol. Oral Cir. Bucal, 10(5):376-87, 2005.

Shah, S. K.; Le, M. C. \& Carpenter, W. M. Retrospective review of pediatric oral lesions from a dental school biopsy service. Pediatr. Dent., 31(1):14-9, 2009.

Shulman, J. D. Prevalence of oral mucosal lesions in children and youths in the USA. Int. J. Paediatr. Dent., 15(2):89-97, 2005.

Siadati, S.; Seyedmajidi, M. \& Sharbatdaran, M. Frequency of different oral lesions in children and adolescents in Babol, Northern Iran. Caspian J. Intern. Med., 4(4):773-6, 2013.

Skinner, R. L.; Davenport, W. D. Jr.; Weir, J. C. \& Carr, R. F. A survey of biopsied oral lesions in pediatric dental patients. Pediatr. Dent., 8(3):163-7, 1986.

Sousa, F. B.; Etges, A.; Corrêa, L.; Mesquita, R. A. \& de Araújo, N. S. Pediatric oral lesions: a 15-year review from São Paulo, Brazil. J. Clin. Pediatr. Dent., 26(4):413-8, 2002.

Vale, E. B.; Ramos-Perez, F. M.; Rodrigues, G. L.; Carvalho, E. J.; Castro, J. F. \& Perez, D. E. A review of oral biopsies in children and adolescents: A clinicopathological study of a case series. J. Clin. Exp. Dent., 5(3):e144-9, 2013.

Wang, Y. L.; Chang, H. H.; Chang, J. Y.; Huang, G. F. \& Guo, M. $\mathrm{K}$. Retrospective survey of biopsied oral lesions in pediatric patients. J. Formos. Med. Assoc., 108(11):862-71, 2009.

Correspondence to:

Josi K. Amadeu

Av. Lothário Meissner 632, Jardim Botânico

CEP: 80210-170

Curitiba - Paraná

BRAZIL

Email: jkamadeu@gmail.com

Received: 21-09-2014

Accepted: 06-03-2015 